\title{
織布の動的ドレープの解析
}

$\begin{array}{lllll}\text { 金沢大学教育学部 } & \text { 松 } & \text { 平 } & \text { 光 } & \text { 男 (会員) } \\ \text { 京都大学工学部 } & \text { 川 } & \text { 端 } & \text { 季 } & \text { 雄 (会員) }\end{array}$

\section{An Analysis of Dynamic Drape of Woven Fabric.}

\author{
Mitsuo Matsudaira*, Member and Sueo Kawabata**, Member \\ *Faculty of Education, Kanazawa University, Kanazawa. \\ **Department of Polymer Chemistry, Kyoto University, Kyoto.
}

\begin{abstract}
In order to investigate dynamic drape of woven fabric, vibrational property of weave was analysed theoretically and experimentally. The motion of weave was considered to be shear deformation and the shear vibrational property was analysed using differential equation. Vibration tester, which was modified KES-LABOMODEL shear tester, was used to examine the motion of the weave. It was shown that weave with buckling like sine wave (buckled-shaped weave) was considered to be equivalent to plate-shaped weave by some correction of weave characteristics such as shear stiffness and weave mass. Women's thin dress fabrics were examined their vibrational properties and their amplitude angles of vibration decreased linearly with time. This means that their shear vibration damp by frictional effect between fibres and/or between warp and weft yarns in the weave and that viscostic effect in the weave can be neglected in the range observed. Viscostic effect of air resistance is also neglected when the length of weave is small (smaller than $0.1 \mathrm{~m}$ ), but it becomes distinct if the length is large (larger than $0.5 \mathrm{~m}$ ). The amplitude damping angle is in proportion to $2 \mathrm{HG}_{0} / \mathrm{G}_{0}$ which are characteristic values of weave shear property measured by KESF system.

(Received 20, June, 1986)
\end{abstract}

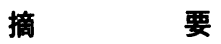

目的 重力場における織布の摇動振動とせん断特性との関係を解析し, 衣服の動的ドレープと布物性との関連を明ら かにする.

成果 平板状の織布および正弦波状に曲げバックリングした織布（屈曲布）の摇動振動特性を布の面内せん断変形特 性と結び付けた．屈曲布の振動は平板布の振動に一部修正を加えることにより取扱えることを明らかにした．婦人用薄手 布の摇動振動は布の面内せん断変形特性での摩擦効果によって減衰し, その減衰角はせん断力のヒステレシスとせん断剛 性との比に直線関係を示す.

(昭和61年 6 月 20 日受理)

\section{1. 緒 言}

曲げバックリング (屈曲) からなる多くのひだの ある衣服が身体の動きに伴って摇動する現象は衣服 着用時の形態の美観に関連している.この現象をこ こでは一括して動的ドレープと呼ぶ.この動的ドレ ープについては,これまでの研究では婦人用スカー トのすその摇動追跡 ${ }^{123}$, あるいはスカートの摇動 と感覚との関係 ${ }^{4.5)}$ な゙が検討されている. またこの 動的ドレープは，一般には布の曲げ変形およびせん 断変形を伴う動きが主体と考えられるため, 布の曲 げ特性と動的ドレープとの関係が詳しく解析され報
告されている 布と呼ぶ）の場合，着用中の屈曲を伴う布地の動き をみると, 屈曲のため曲げ剛性が増大し, 織布特有 の低いせん断剛性による面内せん断変形が主たる役 割を持つ場合が多い. 例えば織布はたて系一よこ系 間の交差角を変化することにより，容易に面内せん 断変形を生じる. 本研究ではせん断変形に基づく動 的ドレープについて解析し, 織布の摇動振動特性と 力学的性質との関連を解明する.

\section{2. 理 論}

織布は一般に面内のせん断剛性が比較的小さく， 


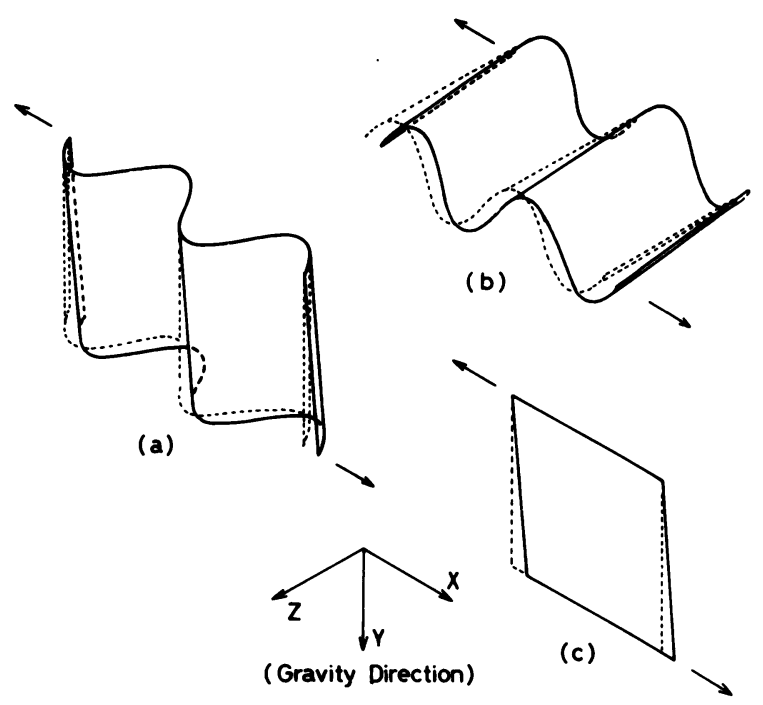

Fig. 1 Three major types of weave vibration.

せん断変形が容易に生じる．図 1(a)，(b)に示すよう に，屈曲した形態の布がわずかに摇動する場合，変 形は布の面内せん断変形が主体となっている，本報 では布の曲げ変形の効果を無視して, 純粋にせん断 変形のみが関係する摇動について検討する. 最も単 純なせん断変形は図 $1(\mathrm{c}) て ゙$, 平板状の織布がせん断 変形により矢印方向（ $X$ 軸方向）へ摇動する場合 であり, まずこの変形について検討する.

\section{1 平板状の識布のせん断播动振动}

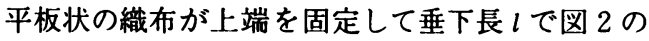
ように垂下している場合を考える．固定端に座標の 原点をとって $X, Y$ 座標を決め, 面内の一様なせん 断変形を伴う $X$ 軸方向への摇動振動を仮定する. いま $X$ 軸方向を布の幅方向と定義し, 布の単位幅 当りの質量を $m_{f}$ とし，一般に単位幅当りの質量 $m_{w}$ の重鍾が布の下端に付加されている場合を考える.

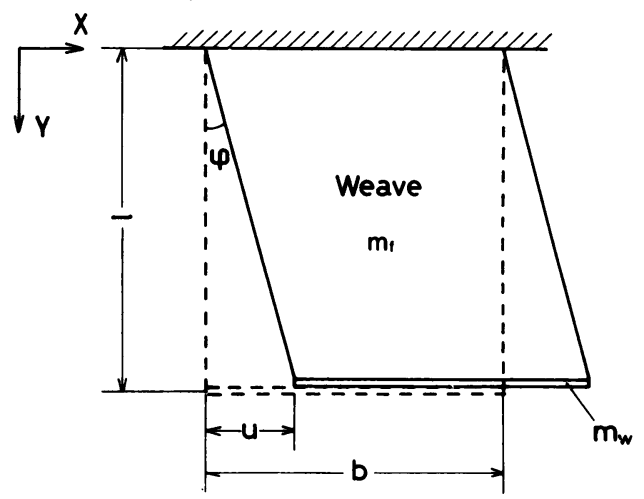

Fig. 2 Vibration model of plate-shaped weave based on shear deformatio.
この考慮は問題の一般化とともに, 実験時の下端振 動検出装置の付加による効果を付与するためでもあ る.布の動的せん断特性に関しては次式を仮定する.

$$
F_{s}=G \varphi \pm H+\eta, \frac{d \varphi}{d t}
$$

ただし， $F_{s}$; 単位幅当りのせん断力 $(\mathrm{N} / \mathrm{m})$

$G$ ；単位幅当りのせん断剛性 $(\mathrm{N} / \mathrm{m} \cdot \mathrm{rad})$ $\varphi$; せん断角 $(\mathrm{rad})$

ク，布のせん断変形における単位幅当りに かかる粘性抵抗係数 $(\mathrm{N} \cdot \mathrm{s} / \mathrm{m} \cdot \mathrm{rad})$

$H$; せん断力 $F$ 。 の内部織維（あるいは糸） 間摩擦によるヒステレシス $(\mathrm{N} / \mathrm{m})$, $X$ 軸の正方向への移動時は正符号, 逆 のときは負符号をとる

$l$; 垂下長 (m)

$b$; 布の幅 (m)

$m_{\digamma}$; 布の単位幅当りの質量 $(\mathrm{kg} / \mathrm{m})$

$m_{w}$; 重鍾の単位幅当りの質量 $(\mathrm{kg} / \mathrm{m})$

布の面内せん断自由振動の運動方程式は $\varphi$ の小さ な領域では次式となる.

$$
I \frac{d^{2} \varphi}{d t^{2}}+C \frac{d \varphi}{d t}+K \varphi \pm D=0
$$

ただし，Iは振動系の慣性 2 次モーメントで,

$$
I=m_{f} l^{2} b / 3+m_{w} l^{2} b
$$

ここで右辺第 1 項は布の慣性項で, 第 2 項は重錘の 慣性項である. C は粘性抵抗係数で, 布自身の粘性 抵抗 ク,によるものと空気の抵抗によるものが含ま れている. 空気抵抗については次のように求められ る. 布の一点 $(x, y)$ における微小面積 $d s$ が受け 
(論文集) Vol. 39, No. 12 (1986)

る両側面からの空気抵抗によるモーメント増加 $d M$ は,

$$
d M=2 \cdot \eta_{a} \cdot \frac{d \varphi}{d t} \cdot y \cdot d s
$$

ただし， $\eta_{a}$ は布の単位面積当りの空気の粘性抵抗 係数 $\left(\mathrm{N} \cdot \mathrm{s} / \mathrm{m}^{2} \cdot \mathrm{rad}\right)$ である. 従って布面での面 積分を求めると,

$$
M=2 \eta_{a} \int_{s} \frac{d \varphi}{d t} \cdot y \cdot d s=\eta_{a} b l^{2} \frac{d \varphi}{d t}
$$

布のせん断変形における粘性効果に基づく抵抗モー メントは $\eta, \cdot b \cdot l d \varphi / d t$ であるから,

$$
C=b l\left(\eta_{1}+\eta_{a} l\right)
$$

また, $K$ は弾性抵抗係数で, $\varphi, m_{f}, m_{w}$ が小さいと きには近似的に

$$
K=b l\left(G+\frac{m_{/} g}{2}+m_{u} g\right)
$$

ただし， $g$ は重力の加速度 $\left(=9.8 \mathrm{~m} / \mathrm{s}^{2}\right)$ である. $D$ は摩擦効果項で,

$$
D= \pm b l H
$$

ただし， $\varphi$ の増加過程では正符号をとり， $\varphi$ の減少 過程では負符号をとる。

(2)式を時刻 $t=0$ において $\varphi=\varphi_{0}$ の条件で解くと, 自由振動の始めの半サイイルについては(2)式の左辺 の正負の符号は負となり，その解は， $C^{2}<4 I K$ の減 衰振動の場合を考えると，

$$
\begin{gathered}
\varphi_{(t)=} \frac{D}{K}+\left(\varphi_{0}-\frac{D}{K}\right) \sqrt{\frac{4 I K}{4 I K-C^{2}}} \cdot e^{-C t / 2 I} . \\
\cos \left(\frac{\sqrt{4 I K-C^{2}}}{2 I} t+\gamma\right)
\end{gathered}
$$

ただし， $\gamma=-\tan ^{-1}\left(C / \sqrt{4 I K-C^{2}}\right)$

$$
\text { 周期 ; } T=4 \pi I / \sqrt{4 I K-C^{2}}
$$

半サイクル後の最大負振幅 $\varphi_{1}$ は,

$$
\varphi_{1}=\frac{D}{K}-\left(\varphi_{0}-\frac{D}{K}\right) \exp \left(\frac{-C(\pi-\gamma)}{\sqrt{4 I K-C^{2}}}\right)
$$

次の戻りの半サイクルについては(2)式の左辺の正負 の符号は正となり，その解は，

$$
\begin{gathered}
\varphi_{(t)}=-\frac{D}{K}+\left(\varphi_{1}+\frac{D}{K}\right) \sqrt{\frac{4 I K}{4 I K-C^{2}}} \cdot e^{-c t / 2 I} . \\
\cos \left(\frac{\sqrt{4 I K-C^{2}}}{2 I} t+\gamma\right)
\end{gathered}
$$

またこのサイクルの終りで速度がゼロになるとき の最大振幅 $\varphi_{2}$ は,

$$
\varphi_{2}=-\frac{D}{K}-\left\{\frac{2 D}{K}-\left(\varphi_{0}-\frac{D}{K}\right) \exp \left(\frac{-C(\pi-\gamma)}{\sqrt{4 I K-C^{2}}}\right)\right\} .
$$

$$
\exp \left(\frac{-C \pi}{\sqrt{4 I K-C^{2}}}\right)
$$

ここで減衰振動の振幅が直線的に減少すれば, 後述 するように粘性効果は存在しないが，振幅が非直線 的に減少する場合には，下記のように粘性効果のみ を分離してそのパラメータを求めることができる. 半サイクルごとの振幅の極大值を求めると,

$$
\begin{aligned}
& \varphi_{0}=\varphi_{0} \\
& \varphi_{1}=\alpha-\left(\varphi_{0}-\alpha\right) e^{-\beta} \\
& \varphi_{2}=-\alpha-\left(\varphi_{1}+\alpha\right) e^{-\beta} \\
& \varphi_{3}=\alpha-\left(\varphi_{2}-\alpha\right) e^{-\beta} \\
& \varphi_{4}=-\alpha-\left(\varphi_{3}+\alpha\right) e^{-\beta}
\end{aligned}
$$$$
\varphi_{m}=(-1)^{m-1} \alpha-\left(\varphi_{m-1}-(-1)^{m-1} \alpha\right) e^{-\beta}
$$

ただし， $\alpha=D / K, \quad \beta=\pi C / \sqrt{4 I K-C^{2}}$ $n=2 m(m \geq 1)$ 番目の極大値に注目すると,

$$
\varphi_{n}=-\alpha-2 \alpha e^{-\beta}-\alpha e^{-2 \beta}+\varphi_{n-1 e^{-2 \beta}}
$$

それ故，

$$
\frac{\varphi_{n+1}-\varphi_{n}}{\varphi_{n}-\varphi_{n-1}}=\exp \left(\frac{-2 \pi C}{\sqrt{4 I K-C^{2}}}\right)
$$

このことは極大値間の差より粘性抵抗 $C$ が求まる ことを示している. (13)式より $\varphi_{n}$ を求めると,

$$
\begin{aligned}
\varphi_{n}=\varphi_{0}-\left(\alpha+2 \alpha e^{-\beta}+\alpha e^{-2 \beta}-\varphi_{0 e^{-2 \beta}}+\varphi_{0}\right) & \\
& \frac{1-e^{-2 \beta(n-1)}}{1-e^{-2 \beta}}
\end{aligned}
$$

となり，(15)式を使って摩擦効果項 $D$ を求めること もできる.

(i) 粘性効果を無視できる場合

(2)式で $C=0$ の場合, 解(9)は,

$$
\varphi_{(t)}=\frac{D}{K}+\left(\varphi_{0}-\frac{D}{K}\right) \cos \sqrt{\frac{K}{I}} t
$$

となり, 次の半サイクルでは, 解(11)は,

$$
\varphi_{(t)}=-\frac{D}{K}+\left(\varphi_{1}+\frac{D}{K}\right) \cos \sqrt{\frac{K}{I}} t
$$

ただし，周期 ; $T=2 \pi \sqrt{I / K}$

角振幅は 1 サイクルごとに

$$
\Delta \varphi=\frac{4 D}{K}=\frac{4 b l H}{K}
$$

だけ減衰し，最大振幅は時間に対して直線的に減少 することを示す.

(ii) 粘性, 弾性抵抗のみが存在する場合 この場合は(2)式で $D=0$ とおき, 解(9)は, 
$\varphi_{(t)}=\varphi_{0} \sqrt{\frac{4 I K}{4 I K-C^{2}}} \cdot e^{-C t / 2 I} \cdot \cos \left(\frac{\sqrt{4 I K-C^{2}}}{2 I} t+\gamma\right)(19)$

ただし, $\gamma=-\tan ^{-1}\left(C / \sqrt{4 I K-C^{2}}\right.$

$$
\text { ; } T=4 \pi I / \sqrt{4 I K-C^{2}}
$$

これは通常の粘弾性の自由減衰振動を示し, 振幅は 指数関数的に減衰する. 極大值の対数を時間に対し てプロットすると直線関係が得られ, その傾き $k$ は,

$$
k=-\frac{C}{2 I}
$$

となり，粘性抵抗 $C$ が求まる，(9)，(11)，(16)，(17)お よび(19)の場合について, 最大振幅値の減少の様子を 図 3 に示す.

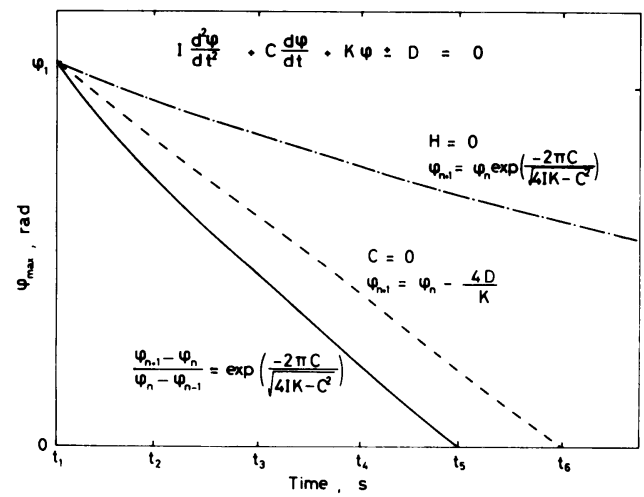

Fig. 3 Damping of maximum amplitude angle with time in shear vibration for three typical conditions.

\section{2 曲げバックリング (屈曲) 形態を持つ織 布のせん断摇動振動}

上端を固定した織布が図 4 のように屈曲を伴っ

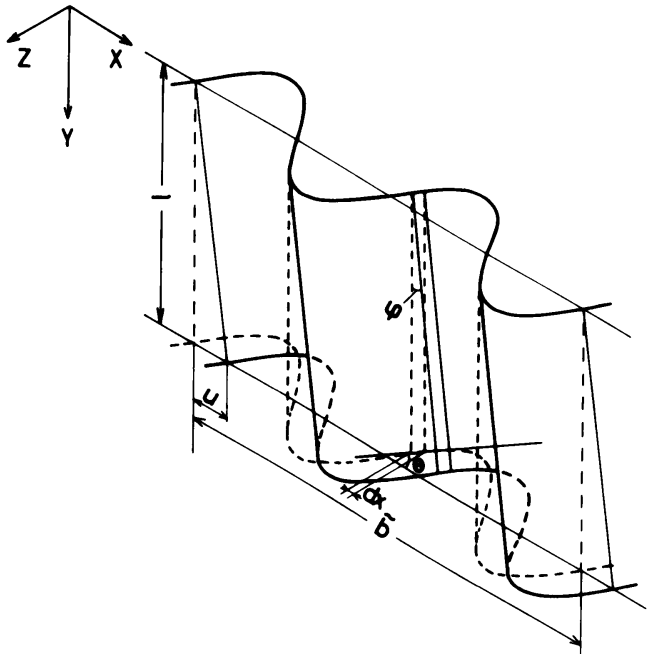

Fig. 4 Vibration model of buckled-shaped weave based on shear deformation.
て， $Y$ 軸方向に長さ $l$ で垂下している場合の $X$ 軸方 向への摇動振動を考える. 布の上端が固定され，下 端が $X$ 軸方向に振動するとき, 厳密には各種の複 雑な変形が混在するものと考えられるが, 前述のよ うな織布では, 布の面内せん断剛性が小さいため, 布のせん断変形のみを考慮すればよい。このことは 観測によっても簡単に確かめることができる. 図 4 に示すように，屈曲した布の下端が $X$ 軸方向に一 様な水平変位 $u$ を持つ場合, 布特性による抵抗力 を求めると次のようになる，屈曲した布の $X-Y$ 平 面へ投影したせん断角 $\varphi$ は,

$$
\varphi=\frac{u}{l}
$$

図 4,5 に示すように， $X$ 軸方向で考えた小区間

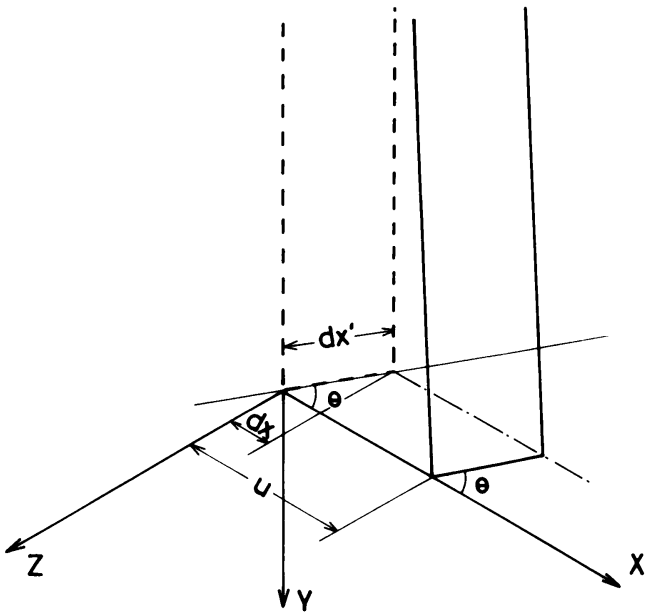

Fig. 5 A part of vibration model of buckled-shaped weave based on shear deformation.

$d x$ の布片と $X-Y$ 平面とのなす角を $\theta$ とすると, その布片に生じているせん断変形のせん断角 $\varphi^{\prime}$ は,

$$
\varphi^{\prime}=\varphi \cos \theta
$$

布片の幅 $d x^{\prime}$ は,

$$
d x^{\prime}=\frac{d x}{\cos \theta}
$$

従って布片の下端にかかる接線力 $d f_{s}^{\prime}$ は,

$$
d f_{s}^{\prime}=\left(G \varphi^{\prime} \pm H+\eta, \frac{d \varphi^{\prime}}{d t}\right) d x^{\prime}
$$

(22)および(23)を(24)式に代入し，かつ $X$ 軸方向へのせ ん断力成分 $d f_{s}$ を求めると,

$$
\begin{aligned}
d f_{s} & =d f_{s}^{\prime} \cos \theta \\
& =\left(G \varphi \cos \theta \pm H+\eta, \cos \theta \frac{d \varphi}{d t}\right) d x
\end{aligned}
$$

$X$ 軸上で測った布幅（X-Y 軸上へ投影した幅）を $\widetilde{b}(\mathrm{~m})$ とし，全布幅について(25)式を積分すると $X$ 
(論文集) Vol. 39, No. 12 (1986)

軸方向の単位幅当りのせん断力 $\widetilde{F}_{s}(\mathrm{~N} / \mathrm{m})$ が求まり,

$$
\widetilde{F}_{s}=\widetilde{G} \varphi \pm H+\widetilde{\eta}_{f} \frac{d \varphi}{d t}
$$

ただし，

$$
\begin{aligned}
& \widetilde{G}=\frac{G}{\widetilde{b}} \int_{0}^{\widetilde{b}}|\cos \theta| d x \\
& \widetilde{\eta}_{f}=\frac{\eta_{f}}{\widetilde{b}} \int_{0}^{\widetilde{b}}|\cos \theta| d x
\end{aligned}
$$

(27)式の積分は屈曲布の屈曲状態で決る定数であり, 振幅 $a$, 波長 $p$ の正弦波形状形態の屈曲布の場合,

$$
S_{1}=\frac{1}{\widetilde{b}} \int_{0}^{\widetilde{b}}|\cos \theta| d x
$$

とすると, $\widetilde{b}$ を $P$ 整数倍にとる場合, $S_{1}$ は表 1 のようになる.

Table 1 Correction Coefficient of Buckled-shaped Weave According to the Sine Wave.

\begin{tabular}{ccccccc}
\hline $\mathrm{p} / \mathrm{a}$ & 1 & $4 / 3$ & 2 & $8 / 3$ & 4 & 8 \\
$\mathrm{~S}_{1}$ & 0.325 & 0.394 & 0.505 & 0.592 & 0.716 & 0.884 \\
$\mathrm{~S}_{2}$ & 4.188 & 3.231 & 2.305 & 1.866 & 1.464 & 1.140 \\
\hline
\end{tabular}

すなわち, 屈曲した布では, その布の特性 $\widetilde{G}$, $\widetilde{\eta}_{f}$ を,

$$
\left.\begin{array}{l}
\widetilde{G}=S_{1} G \\
\widetilde{\eta}_{f}=S_{1} \eta_{j}
\end{array}\right\}
$$

と置換することにより，平板状の布と同等に取扱う ことができる。

布の質量については, 単位幅当りの質量は屈曲す ることにより見掛け上増大することになり, 振幅 $a$, 波長 $P$ の正弦波の場合,

$$
S_{2}=\frac{1}{\widetilde{b}} \int_{0}^{\widetilde{b}} \frac{d x}{|\cos \theta|}
$$

とすると, $S_{2}$ は表 1 のようになる.

すなわち, 屈曲した布では, 布および重錘の質量 $\widetilde{m}_{f}, \widetilde{m}_{w}$ を,

$$
\left.\begin{array}{l}
\widetilde{m}_{f}=S_{2} m_{f} \\
\tilde{m}_{w}=S_{2 m_{w}}
\end{array}\right\}
$$

と置換することにより, 平板状の布と同等に取扱う ことができる.

空気の粘性抵抗については, 形態が異なるため, 新しい粘抵抗係数 $\widetilde{\eta}_{a}$ が必要であり, これの誘導は 複雑であり，後述するように計測によって求める必 要がある。

以上のように, 屈曲形態を持つ布のせん断摇動振 動については， $X-Y$ 平面上への投影面が作る平板
状の布の振動に置換することができる。すなわち, (2)式の運動方程式の係数だけを変えて適用できるこ とを理論的に結論づけることができる.

\section{3. 実 験}

\section{1 実験方法}

まず平板状試料により布の自由摇動振動特性とせ ん断特性との関係を求め,また空気抵抗などの粘性 効果の有無を調べた．実験に用いたせん断振動試験 機は, KES-LABO-MODEL-F3 せん断テスタを改良 したもので, 布の下端に線状の剛体重錘 $(0.2 \mathrm{~kg} / \mathrm{m})$ を付加し，下端の移動量 $u$ を検出するため，差動 トランスのコアを取付けた。 試料布の寸法は, $l=$ $0.05 \mathrm{~m}, \quad b=0.2 \mathrm{~m}$ で KESF システム ${ }^{9}$ の標準試験 ${ }^{10)}$ に用いられる寸法に基づいた.これは KESF システ ムで常用されるせん断特性值であるせん断剛性 $G$ やせん断力のヒステレシス $2 H G$ と関連づけるため である。

次に試料布の寸法として $l=0.05 \mathrm{~m}, \widetilde{b}=0.2 \mathrm{~m}$ とした屈曲状試料の自由摇動振動実験を行い, 理論 式(29)および(31)の妥当性について検討した. 布の屈曲 形態としては振幅対波長の比を 1 対 4 とした正弦波 形状とし，1 波長分の試料について検討した。図 6 に屈曲状試料の実験の様子を写真で示す．空気抵抗

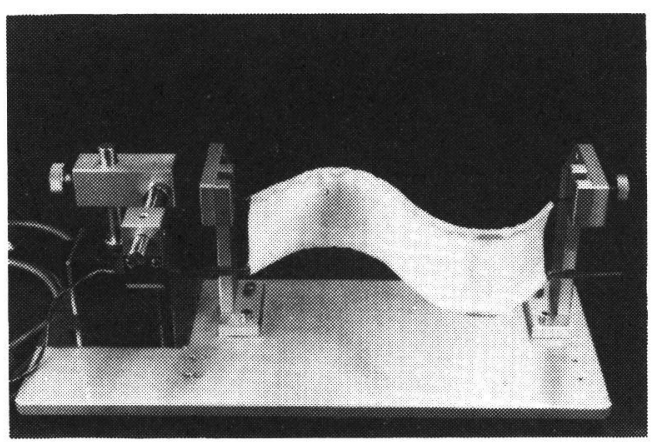

Fig. 6 An appearance of experiment for the buckled-shaped weave by the modified KESLABO-MODEL shear tester (vibration tester).

の寄与を検討するため, アクリル製の真空箱中 $(4.0$ - $\left.10^{3} \mathrm{~Pa}\right)$ でも振動実験を行い, 大気圧下 (1.0 ・ $\left.10^{5} \mathrm{~Pa}\right)$ の結果と比較した. 実験はすべて $22 \pm 3^{\circ} \mathrm{C}$, $60 \pm 10 \%$ RH 環境下で行った。

\section{2 試 料}

動的ドレープ特性が外観上重要視される婦人用薄 手布 ${ }^{11}$ を選び，その中で多用されている織物のうち， たて系，よこ糸ともに無撚のフィラメント糸よりな 
Table 2 Outlines of Samples

\begin{tabular}{lllccc}
\hline & Name & Yarn & $\begin{array}{c}\text { Sample } \\
\text { Number }\end{array}$ & $\begin{array}{c}\text { Thickness } \\
(\mathrm{mm})\end{array}$ & $\begin{array}{c}\text { Weight } \\
\left(\mathrm{g} / \mathrm{m}^{2}\right)\end{array}$ \\
\hline Silk & Habutae & Filament & 5 & $0.13-0.24$ & $50-110$ \\
Polyester* & Habutae & Filament & 5 & $0.09-0.22$ & $50-80$ \\
Rayon & Habutae & Filament & 5 & $0.09-0.15$ & $60-80$ \\
Cupra & Habutae & Filament & 6 & $0.09-0.12$ & $70-100$ \\
Acetate & Habutae & Filament & 5 & $0.12-0.16$ & $60-100$ \\
Nylon & Habutae & Filament & 5 & $0.09-0.11$ & $50-70$ \\
\hline
\end{tabular}

* These polyester weaves are called silk-like polyester.

る羽二重を用いた。試料の概略を表 2 に示す.

\section{4. 結 果}

\section{1 平板状の樴布のせん断摇動振動特性}

平板状の布のせん断摇動自由減衰振動特性の結果 例を図 7 に示す。これは表 2 の試料中で減衰が最も 遅いレーヨン布の結果で, 減衰挙動をみると, 振動 数 $2.5 \mathrm{~Hz}$ で, 振幅が時間に対して直線的に減少し ていることがわかる.この減衰挙動は他の試料につ いても同様であった，すなわち，このせん断変形振 動では, 実験の振動数範囲 $(2 \sim 4 \mathrm{~Hz})$ では, 布 の減衰振動特性がせん断特性のヒステレシス $H$ に

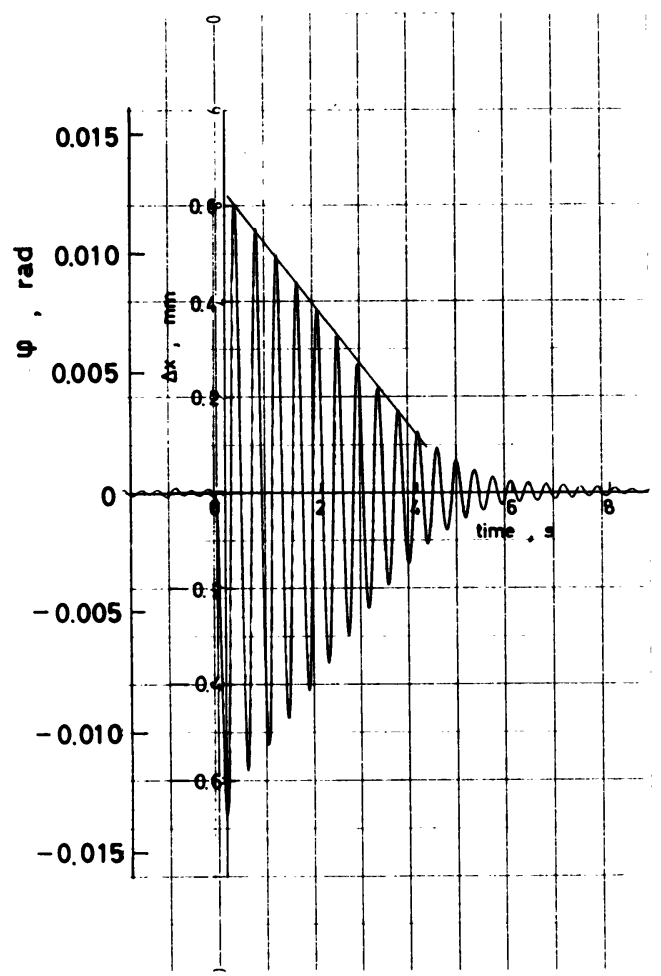

Fig. 7 An example of weave shear vibration obtained by the vibration tester.
起因し，空気の粘性抵抗を含む粘性効果が無視し得 ることを示している．布のせん断変形におけるせん 断力のヒステレシスは交差系間あるいは繊維間の摩 擦力に基づくと考えられるので，このクーロン摩擦 がせん断振動の減衰特性を与えることになる.

減衰直線の傾きを表 2 の試料について求め, 素材 別の群内平均值を用いて振動の隇衰特性をモデル化 して図 8 に示す. 各試料群内の標準偏差も示した.

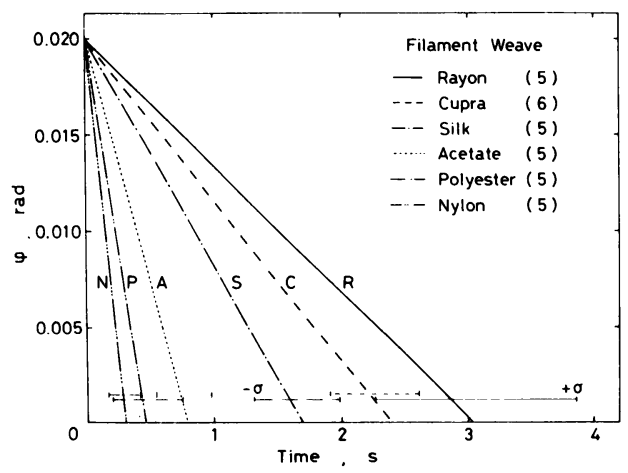

Fig. 8 Relationship between maximum amplitude angle of weave shear vibration and time for various filament weaves.

レーヨン,キュプラおよびシルク布は隇衰が小さく， 振動が長く持続し，ポリエステルやナイロン布では 減衰が大きいことが明らかに示されている．ここで 扱ったポリエステル布はシルクを模做して製造さ れ，いわゆるシルクライクポリエステル12.13)として 市販されている布であるが, シルクに比べると減衰 が大きい.

\subsection{KESF システムで得られるせん断特性值 との対応}

表 2 の試料について KESF システムを用いて布の 面内せん断変形の特性值, すなわち, せん断剛性 $G$ およびせん断力のヒステレシス $2 H G$ を測定した。 ただし，振動実験条件と対応させるため，布張力； 
$1.96 \mathrm{~N} / \mathrm{m}$, 最大せん断角 ; $\pm 0.035 \mathrm{rad}$ の条件下で 測定した。せん断角ゼロ $\mathrm{rad}$ におけるせん断剛性 $G_{0}$ 抢よびヒステレシス $2 H G_{0}$ を考える. 角振幅の 減少である(18)式は, $G=G_{0}, H=H G_{0}$ とおくと,

$$
\Delta \varphi=\frac{4 b l H G_{0}}{G_{0}} /\left(1+\frac{m_{i} g}{2 G_{0}}+\frac{m_{w} g}{G_{0}}\right)
$$

となる，そこで表 2 の試料について振動実験より求 めた実測值 $\Delta \varphi$ と $2 H G_{0} / G_{0}$ との関係を図 9 に示す. $\Delta \varphi$ と $2 H G_{0} / G_{0}$ との間には明らかな直線関係が成 立し, 相関係数 $r=0.97$ で,

$$
\Delta \varphi=1.57 \frac{2 H G_{0}}{G_{0}}-0.0029
$$

なる回帰式が得られる，次に(32)式を用いて算出した $\Delta \varphi$ と $2 H G_{0} / G_{0}$ との相関を求めると, 係数 $r=0.97$ で,

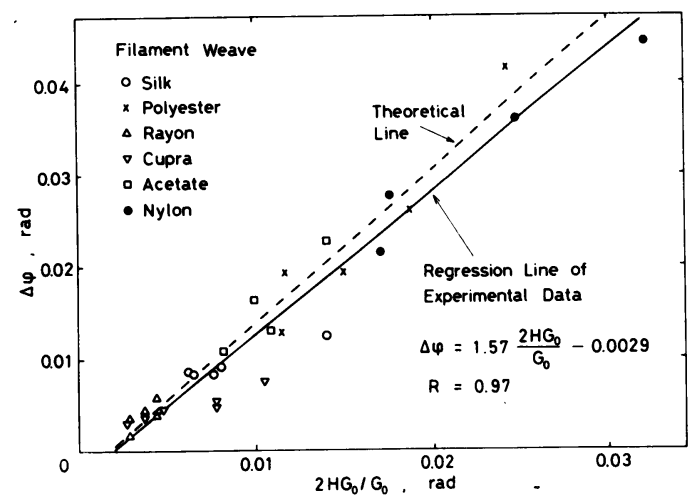

Fig. 9 Relationship between amplitude damping angle and shear characteristics for various filament weaves.

$$
\Delta \varphi=1.66 \frac{2 H G_{0}}{G_{0}}-0.0027
$$

となり，(33)式と極めて良く一致している.すなわち， $\Delta \varphi$ と $2 H G_{0} / G_{0}$ との間には直線関係が成立し, $2 H G_{0} / G_{0}$ が小さいほど減衰の振幅角減衰量 $\Delta \varphi$ が小 さく，良く振動することを示している．このことは $\mathrm{KESF}$ システムで得られる $2 H G_{0}, G_{0}$ より布のせん 断摇動振動特性を推定できることを意味している. また，逆に布のせん断振動実験を行うことにより， 振動の減衰する様子から布内の粘性抵抗や空気抵抗 の有無を推定でき, 摩擦項のみで減衰する場合には その振幅角減少量より摩擦に基づくヒステレシスと せん断剛性との比を推定することができる.従って, 簡単なせん断振動実験を行うことにより，布内にお けるヒステレシス効果を確認でき，実際の垂下布の 摇動を近似的かつ直接的に推定することができる.

\section{3 屈曲状の織布のせん断力の点検}

形態保持の難しい屈曲布のせん断抵抗力を精密に 測定することは困難であったので, 直線状に屈曲し た布 1 波長に相当する形態で, かつ力学的対称性を もたせた形態の布を用いてモデル実験を行った．図 10(a)に示すように，振動方向（ $X$ 軸方向）と一定角 度 $\pi / 4$ で交わる 2 枚の布を, $X$ 軸方向へせん断変 形させたときのせん断力 $2 \widetilde{F}$ sを測定した.ここで 得られた $\widetilde{F}, と$, 図10(b)のように $X$ 軸方向と平行な 1 枚の布のせん断力 $F_{s}$ とを比較したところ, せん 断剛性 $G$ とせん断力のヒステレシス $H$ は,

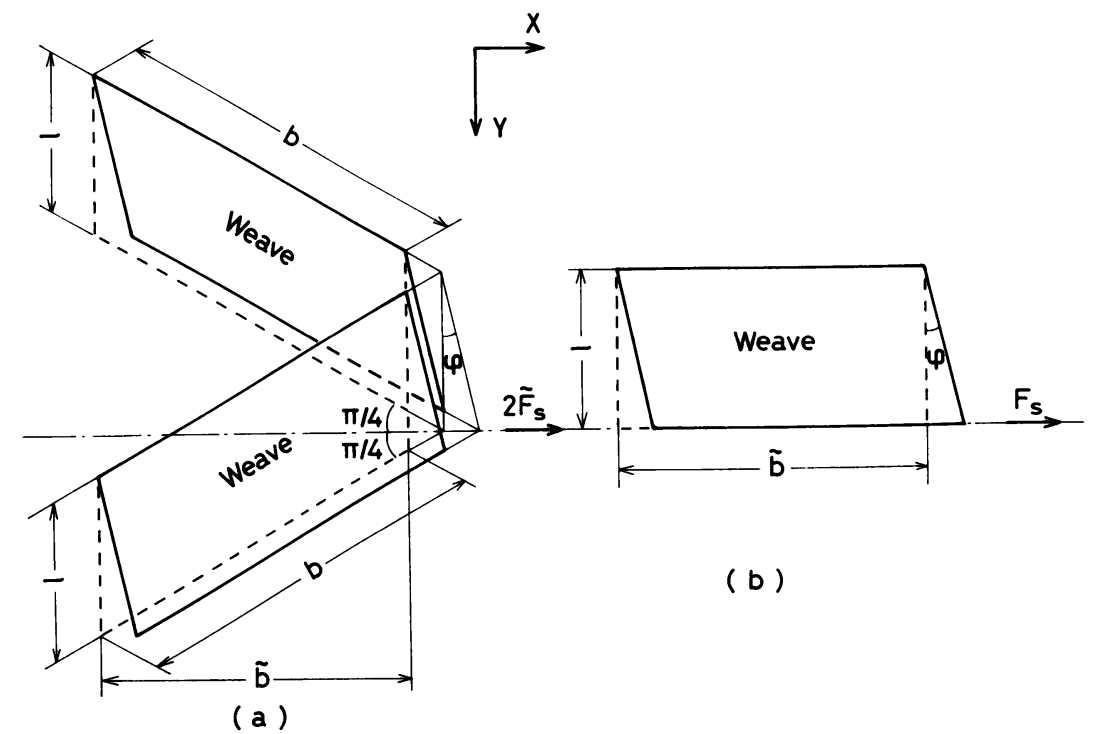

Fig. 10 Shear deformation of plate-shaped weave having $\pi / 4$ inclined plane (a) and parallel plane (b) to the deformation direction. 


$$
\begin{aligned}
\widetilde{G} & =0.73 G \\
\widetilde{H} & =0.95 H
\end{aligned}
$$

なる関係が得られた. (29)式の関係を使って屈曲布の 値を算出すると,

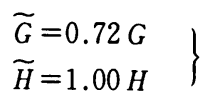

これは実測値と良く一致する.

\section{4 屈曲状の識布のせん断摇动振陻特性}

振幅対波長の比を 1 対 4 とした正弦波形状に屈曲 した試料を用いて振動実験を行った。 その結果, 屈 曲布の隇衰挙動は 4.1 で示した平板状の布と同様, 振動の角振幅が時間に対して直線的に減少する傾向 を得た. そこでレーヨン布 1 種類について減衰振動 の減衰角および周期を厳密に測定し，(29)式および(31) 式の置換による修正を施したせん断特性値より理論 的に算出した減衰角および周期と比較して表 3 に示 す. せん断剛性, 布および重錘の質量を, (29)式およ び(31)式で表される置換を行うことにより，無修正の 結果に比べ, 理論値と実測値とがより良く一致する ことが確認された.このことは, 前述の 4.3 の結果 と併せて，(29)および(31)式で示される置換が妥当であ り，この置換により屈曲布を平板状の布と同等に取 扱うことができることを実験的に証明している.

\section{5 織布のせん断摇㒭振動に及ぼす空気抵抗 効果}

平板状試料の場合も屈曲状試料の場合も垂下長が 小さい $(l=0.05 \mathrm{~m})$ 試料では, 大気圧下 $(1.0$. $\left.10^{5} \mathrm{~Pa}\right)$ および真空下 $\left(4.0 \cdot 10^{3} \mathrm{~Pa}\right)$ とも振動特性 において差異は認められず, 両条件下とも角振幅は 時間に対して直線的に減少した. すなわち，(2)式の $C=0$ であり, 布の粘性抵抗 $\eta_{f}$ および空気の粘抵抗 $\eta_{a}$ ともに無視し得る量であった.

ただし，屈曲状試料で垂下長を10倍（l=0.5 m) にした場合, 減衰振動の角振幅隇衰は非直線的とな り，粘性抵抗が効くようになった，布の粘性抵抗は 前述の実験で無視できることがわかっているので, この粘性抵抗は空気の抵抗と思われる. 例えば試料 の屈曲形状の振幅対波長の比を 1 対 4 とした正弦波 形状の屈曲試料の場合, (14)式より $C$ を求め, (6)式 を用いて空気抵抗を算出すると, $\widetilde{\eta}_{a}=4.3 \cdot 10^{-2}(\mathrm{~N}$ $\left.\cdot \mathrm{s} / \mathrm{m}^{2} \cdot \mathrm{rad}\right)$ を得た（6)式よりわかるように，空 気抵抗による粘性効果は $\eta_{a} \times$ 垂下長の関係になっ ており，垂下長の大きな試料では無視できない量と なる.

\section{5. 考察}

織布のせん断特性は布の張力によって変化する が14), 今回の実験では重錘の質量が小さな領域であ る $\left(m_{w} \leq 0.2 \mathrm{~kg} / \mathrm{m}\right)$ ものの，布自体の質量に比べ て大きく $\left(m_{w}>20 m_{f}\right)$, 布にかかる張力は均一状態 にあると近似した。布のせん断特性はせん断角にも 大きく依存するが(14), 一般の摇動振動ではせん断角 が小さく，せん断角依存性が顕著にならない範囲で あるから，このことはそれほど問題にならない.

重錘を取除いた場合，布にかかる張力は自重によ って分布するが, 布の自重程度の張力では布のせん 断特性に大きな影響を与えず, せん断剛性やヒステ レシスも一定値を示す ${ }^{14)}$. すなわち $G$ および $H$ を

Table 3 Comparison of the Experimental Results with Calculated Results for the Amplitude Damping Angle and Periodic Time of the Shear Vibration.

\begin{tabular}{lcccc}
\hline & $\begin{array}{l}\Delta \text { experiment } \\
\text { (rad) }\end{array}$ & $\begin{array}{c}\Delta \varphi_{\text {theory }} \\
\text { (rad) }\end{array}$ & $\begin{array}{c}\mathrm{T}_{\text {exp. }} \\
(\mathrm{s})\end{array}$ & $\begin{array}{c}\mathrm{T}_{\text {the. }} \\
(\mathrm{s})\end{array}$ \\
\hline $\begin{array}{l}\text { Buckled-shaped } \\
\text { Weave }\end{array}$ & $4.4 \times 10^{-3}$ & $4.51 \times 10^{-3} *$ & 0.35 & $0.357 *$ \\
& $4.63 \times 10^{-3}$ & & 0.307 \\
$\begin{array}{l}\text { Plate-shaped } \\
\text { Weave }\end{array}$ & $4.0 \times 10^{-3}$ & $4.04 \times 10^{-3}$ & 0.33 & 0.327 \\
\hline
\end{tabular}

* Shear stiffness and mass are corrected according to the sine wave of the buckled-shaped weave. 
(論文集) Vol. 39, No. 12 (1986)

一定値とみなせるので本理論式の適用が可能であ る. 衣服の実際の摇動はこのような場合が多いと考 えられる。

より垂下長の大きなカーテンのような場合，ある いは自重が極端に大きな布の場合, 自重の効果が現 われると思われるが，この場合には試料を張力分布 に従っていくつかの層に分割し，おのおのの層の張 力に対応する $G$ および $H$ を用いて本理論式が適用 できる.

布の自重が影響しない図 1 (b)のような水平に横た わる屈曲布の場合, 重力効果による振動回復力をゼ ロとして一般式より導くことができる.この場合振 動は $G$ が回復力となり，布の質量を振動させる.

実際の衣服の動的ドレープとの対応はできなかっ たが, 本報ではモデル化したせん断摇動振動に基づ く動的ドレープの基礎理論について検討した，今後 は実際の衣服の動的ドレープ挙動, またそれと美観 との対応などを検討したい.

\section{6. 結 論}

垂下状態にある織布の摇動振動特性を調べるた め, 小せん断変形領域（<0.04 rad）における平板 状の布および屈曲状の (曲げバックリングを伴った) 布のせん断振動について理論的に検討した．併せて 基本的な実験を行い, 次の結論を得た.

（1）平板状の衣服用織布は一般に，2 $24 \mathrm{~Hz}$ の 振動数域で垂下長が小さい $(<0.1 \mathrm{~m})$ 場合, そのせん断摇動振動の減衰はほとんどせん断の ヒステレシス効果に起因する.

（2）屈曲状の布のせん断摇動振動は, 正弦波形状 に屈曲した布の場合，それと等価な平板状の布 に置換でき，せん断剛性やヒステレシスも平板
状の布の值を修正した値を用いて解析できる. ただし，垂下長が大きい（ $\geq 0.5 \mathrm{~m} ）$ 場合，空 気抵抗による粘性効果が現れる.

（3）織布のせん断変形時における粘性抵抗は本実 験摇動現象の範囲内では無視できる量である.

(4) せん断振動における振幅角の減衰量は, KESF システムで得られるせん断角ゼロにおけ るせん断力のヒステレシスとせん断郕性との比 $2 H G_{0} / G_{0}$ と直線関係を示し, $2 H G_{0} / G_{0}$ を布の 摇動振動特性の特性值として扱うことができ る.この特性値を用いて布の摇動挙動を推定で きる。

（5）振動テスタを用いる簡単な実験により，織布 内の摩擦効果と粘性効果の有無を推定でき, 織 布の摇動挙動に関係する基本的なパラメー夕を 分離できる.

\section{文献}

1) .1:野，木村，長谷川；䋐消誌，16，404（1975）

2) 上野, 江幡：覀消誌，17，43 (1976)

3）上野, 江幡, 大洞 ; 戟消誌, 18, 301 (1977)

4）㷉斗, 小林, 山田：峨学誌，33，T-470 (1977)

5）小林, 㰮斗：轹機誌, 33, P 304 (1980)

6）泉，丹羽：家政学雑誌，32，390（1981）

7）泉, 丹羽：家政学雑誌，34，96（1983）

8) K. Izumi and M. Niwa ; Proceedings of 3'rd Japan-Australia Joint Symposium, p. 725, 日本䋐維機械学会 (1986)

9）川端；瀻機誌, 26, P 721 (1973)

10）川端：“風合い評価の標準化と解析”第 2 版, 日本䄉維機 械学会 (1980)

11) S. Kawabata : "HESC Standard of Hand Evaluation" vol. 2. 日本瀻維機械学会 (1980)

12) 和田；䄉学誌，37，P 429 (1981)

13) 三石 : 阵学誌, 38, P 42 (1982)

14）松平，川端，丹羽；蝺機誌，37，T 49（1984） 